\title{
Pathologic Burden of New Tumor
}

National Cancer Institute

\section{Source}

National Cancer Institute. Pathologic Burden of New Tumor. NCI Thesaurus. Code C158777.

The estimate of the number of cells, or size of the tumor from the results of a pathology examination. 